\title{
Global Halal Center - Unissula mengabdi untuk menyelamatkan umat melalui penyusunan istrumen Muslim Friendly
}

\author{
${ }^{1}$ Suryono* ${ }^{2}$ Yani Istadi, ${ }^{3}$ Rahmawati S. Praptiningsih, ${ }^{4}$ Hudan Taufiq, \\ ${ }^{5}$ Sukijan Athoillah, ${ }^{6}$ Widiyanto \\ ${ }^{1}$ Departemen Periodonsia, Fakultas Kedokteran Gigi, Universitas Gadjah Mada, Yogyakarta, Indonesia. \\ Global Halal Center- Universitas Islam Sultan Agung, Semarang, Indonesia \\ ${ }^{2}$ Fakultas Kedokteran, Universitas Islam Sultan Agung, Semarang \\ ${ }^{3}$ Fakultas Kedokteran Gigi, Universitas Islam Sultan Agung, Semarang \\ ${ }^{4}$ Prodi Farmasi, Fakultas Kedokteran, Universitas Islam Sultan Agung, Semarang \\ ${ }^{5}$ Fakultas Agama Islam, Universitas Islam Sultan Agung, Semarang \\ ${ }^{6}$ Fakultas Ekonomi, Universitas Islam Sultan Agung, Semarang \\ *Corresponding Author \\ suryonodent@mail.ugm.ac.id
}

\begin{abstract}
Abstrak
Indonesia adalah negara dengan mayoritas penduduk beragama Islam, dengan jumlah lebih dari $87 \%$ total penduduknya. Jumlah yang tidak kecil ini merupakan sasaran yang harus diselamatkan dari fasilitas pelayanan barang dan jasa yang merugikan dari sisi peribadatan mereka. Memberikan jaminan aman dari sisi penyedia jasa adalah langkah yang akan ditempuh oleh pusat studi Global Halal Center-UNISSULA(PS GHCU), melalui upaya penciptaan instrumen Muslim Friendly berbagai sektor jasa. Tujuan dari aktifitas yang dilakukan oleh GHCU adalah membuat instrumen yang bisa digunakan untuk mengkualifikasikan tingkat keamanan menurut nilai-nilai Islam (Muslim Friendly) dari suatu unit/lembaga yang memberikan pelayanan jasa pada konsumen/pelanggan muslim, dalam kategori pratama, utama dan paripurna. Proses penyusunan dilakukan melalui kegiatan seminar dan workshop yang mengikutkan peserta masyarakat umum, akademisi dan mahasiswa dengan narasumber dari Majelis Ulama Indonesia, Badan Penyelenggara Jaminan Produk Halal, Institute Pengkajian Halal Malaysia, dan Majelis Upaya Kesehatan Syariah Indonesia. Hasil dari aktivitas kegiatan ini adalah lima instrumen pokok dalam sektor jasa yang meliputi Muslim Friendly for Dental Clinic Rating System, Muslim Friendly for Pharmacy Rating System, Muslim Friendly for Aesthetic Clinic Rating System, Muslim Friendly for Microfinance Rating System, dan Muslim Friendly for Slaughterhouse Rating System.
\end{abstract}

Kata kunci: Apotek, keuangan mikro, klinik, Muslim Friendly, pemotongan hewan

\section{Abstract}

Indonesia is a country with a majority of the population of Islam, with more than $87 \%$ of the total population. This population must be saved from the service 
facilities of goods and services that harm their worship. Providing safe guarantees from the service provider side is a step that will be taken by the Global Halal Center-UNISSULA (PS GHCU) study center, through efforts to create a "Muslim Friendly" instrument in various service sectors. The purpose of the activities carried out by GHCU is to create instruments that can be used to qualify the level of security according to Muslim Friendly values of a unit / institution that provides services to Muslim consumers / customers, in the pre-primary, primary and plenary categories. The drafting process was carried out through seminars and Workshops that included general public participants, academics and students with speakers from the Indonesian Ulema Council, Halal Product Guarantee Organizing Agency, Malaysian Halal Assessment Institute, and Indonesian Sharia Health Effort Assembly. The results of these activities are the five main instruments in the service sector which include Muslim Friendly for Dental Clinic Rating System, Muslim Friendly Pharmacy Rating System, Muslim Friendly for Aesthetic Clinic Rating System, Muslim Friendly for Microfinance Rating System, and Muslim Friendly for Slaughterhouse Rating System.

Keywords: Pharmacy, microfinance, clinics, Muslim Friendly, animal slaughter

\section{PENDAHULUAN}

Data statistik kependudukan Indonesia menunjukkan bahwa lebih dari 85\% penduduk Indonesia beragama Islam. Jumlah yang cukup besar ini merupakan pengguna sebagian besar pelayanan publik yang ada di Indonesia. Universitas Islam Sultan Agung Semarang (UNISSULA) sebagai perguruan tinggi Islam sudah sewajarnya untuk ikut memikirkan keselamatan umat, khususnya dari pelayanan jasa yang bertentangan dengan nilai-nilai Islam sehingga merugikan mereka. Sebagai contoh studi yang dilakukan oleh peneliti Universitas Gadjah Mada (UGM) pada bakso menunjukkan 8 dari 20 sampel bakso positif Deoxyribonucleic acid (DNA) babi, yang tentu sangat merugikan pengguna sektor jasa wisata khususnya berhubungan dengan wisata kuliner. Positif DNA babi bisa karena ada unsur kesengajaan ditambahkan atau tidak sengaja karena tercemar ditempat penggilingan daging. Adanya kondisi seperti ini tidaklah mendukung program-program pengembangan industri sektor jasa seperti pariwisata yang ramah Muslim (Muslim Friendly), sebagaimana telah dikembangkan di beberapa daerah seperti di Toraja dan sumatera barat, (Sigit, 2016) (Aminah, 2019). Dalam bidang kesehatan khususnya pelayanan oleh dokter gigi kadang tanpa disadari menggunakan obat atau material yang diharamkan oleh ajaran Islam, sehingga menjadi tantangan bagi peneliti muslim untuk selalu berupaya melakukan penelitian alternatifnya melalui penguatan produk herbal.(Suryono, 2015)(Suryono et al., 2017)

Dalam rangka penyelenggaran seminar dan workshop, Global Halal Centre (GHC) UNISSULA telah melakukan survei secara terbuka pada masyarakat melalui media sosial dan 
grup WhatsApp. Survei tersebut mendapatkan informasi bahwa masyarakat menginginkan adanya pelayanan sektor jasa yang aman dan terhindar dari hal-hal yang bertentangan dengan ajaran Islam. Sektor jasa tersebut meliputi jasa pelayanan kesehatan seperti klinik, pelayanan apotek, sektor jasa keuangan yang berhubungan dengan simpan pinjam, jasa penyembelihan hewan ternak, penggilingan daging, tempat pendidikan pelatihan, sektor jasa pariwisata termasuk di dalamnya perhotelan, restoran dan tempat wisata kuliner. Hasil survei yang ditunjukkan pada gambar 1, menggambarkan bahwa pelaku usaha penyedia jasa sangat menginginkan adanya sertifikasi keamanan dengan beragam alasan di antaranya ada yang memberikan alasan untuk jaminan aman beribadah bagi pelanggannya, tidak ikut berdosa, hingga alasan bisnis, yaitu untuk lebih banyak mengundang konsumen muslim, mengingat masyarakat muslim merupakan potensi pasar yang besar.

Sertifikasi Halal merupakan kebutuhan pasar bagi konsumen muslim. Kebutuhan itu tidak hanya disikapi secara positif oleh negara-negara dengan mayoritas muslim tetapi juga oleh negara dengan minoritas muslim seperti Korea dan Jepang (Anugeraha, 2014). Korea merupakan negara yang sangat progresif melihat peluang pasar muslim yang potensial, di antaranya menerbitkan buku panduan restoran halal di Korea untuk mendukung perkembangan sektor jasa pariwisatanya.(Sojung, 2015).

Berbasis hasil survei tersebut Pusat Studi Global Halal Center UNISSULA (PS-GHCU) menyusun prioritas topik sektor jasa yang akan dilaksanakan dalam workshop dengan luaran instrumen. Metode yang dilakukan dalam kegiatan ini adalah melalui seminar dan workshop dengan mengundang narasumber dari Majelis Ulama Indonesia oleh Ketua MUI Jateng, Ketua Badan Penyelenggara Jaminan Produk Halal (BPJPH), Ketua Kajian Riset Halal Malaysia (INHART), dan Ketua Majelis Upaya Kesehatan Islam Seluruh Indonesia (MUKISI). Peserta seminar meliputi masyarakat umum, peminat halal, mahasiswa dan dosen. Tema seminar yang diangkat adalah Sertifikasi Sektor Jasa di Era Revolusi Industry 4.0; Kebijakan, Peluang dan Tantangan.
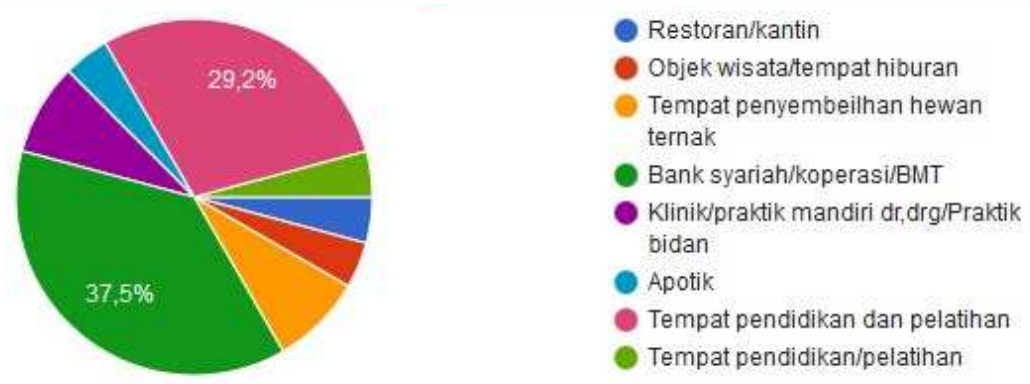

Tempat pendidikan/pelatihan 
Indonesian Journal of Community Services

E-ISSN: 2684-8619

Volume 1, No. 1, May 2019

http://jurnal.unissula.ac.id/index.php/ijocs DOI: http://dx.doi.org/10.30659/ijocs.1.1.1-15

Gambar 1. Hasil survei terbuka oleh Pusat Studi Global Halal Center UNISSULA tentang sektor jasa yang diharapkan mendapat sertifikasi halal dalam pelayanan jasa

Hasil survei terkait sektor jasa yang diinginkan oleh pengguna untuk mendapatkan sertifikasi halal oleh PSHG ditindaklanjuti pada lembaga penyelenggara layanan jasa terkait melalui survey online untuk mendapatkan informasi lebih lanjut. Lembaga penyelenggara layanan jasa yang memberikan respon di antaranya dari pengelola BMT, klinik gigi, klinik kecantikan, apotik dan tempat penyembelihan hewan ternak, dengan rangkuman sebagaimana ditunjukkan dalam gambar 2 adalah sebagian besar (lebih dari 94,4\%) dari 18 tempat penyelenggara layanan jasa yang memberikan tanggapan menyatakan belum pernah mendapatkan sertifikasi halal atau sertifikasi sejenisnya yang berorientasi untuk kepentingan konsumen. Pada dasarnya para pengelola lembaga menginginkan adanya pembinaan dan labelisasi. Beberapa alasan pengelola untuk mendapatkan labelisasi adalah untuk jaminan produknya aman pada konsumen muslim, memberikan penghormatan dan fasilitasi terhadap hak-hak konsumen dari sisi ajaran agama, dan kepentingan bisnis karena pangsa pasar yang potensial. (Suryono, 2015)

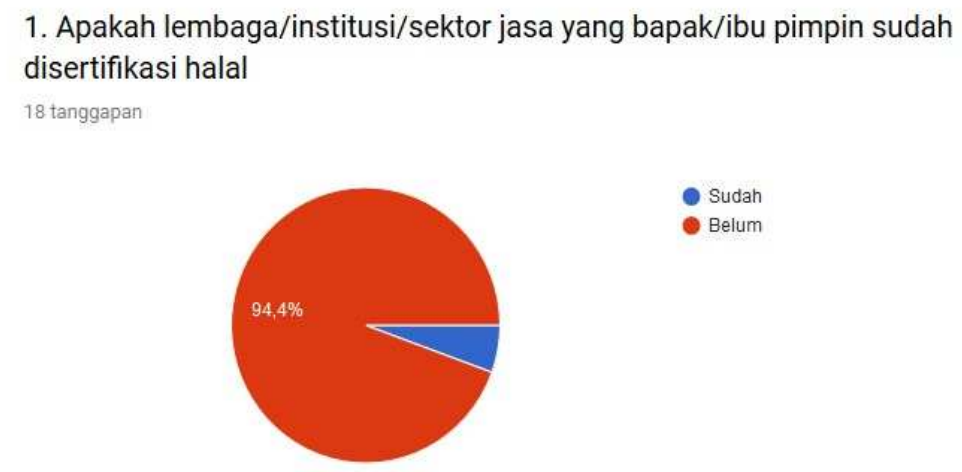

Gambar 2. Hasil survei oleh Pusat Studi Global Halal Center UNISSULA terhadap pengelola sektor jasa dan alasan keinginan label halal.

\section{METODE}

Sosialisasi untuk rekruitmen peserta seminar dan workshop dilakukan melalui penyebaran leaflet via medsos dan mengirimkan surat formal ke berbagai perguruan tinggi di Indonesia, dengan target 200 peserta seminar, dan 5 kelompok workshop penyusunan standar kualifikasi. 
Indonesian Journal of Community Services

E-ISSN: 2684-8619

Volume 1, No. 1, May 2019

http://jurnal.unissula.ac.id/index.php/ijocs DOI: http://dx.doi.org/10.30659/ijocs.1.1.1-15

Topik sektor jasa yang akan disusun instrumennya diperoleh dari survei melalui media sosial dengan menggunakan Google Form.

Seminar dilakukan dengan metode panel, dengan cara para narasumber diberi waktu secara bergantian untuk menyampaikan gagasan, dilanjutkan sesi diskusi yang dipimpin oleh moderator.

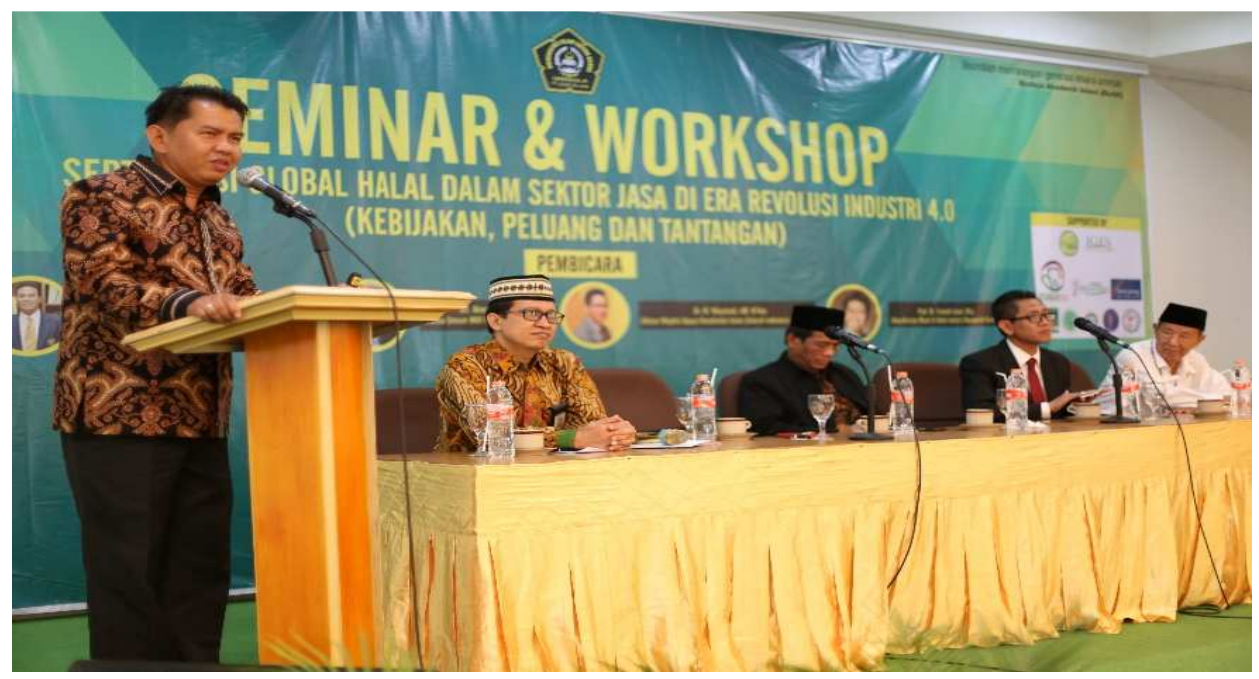

Gambar 3. Pemaparan dalam seminar oleh narasumber (MUI, MUKISI, BPJPH, INHART).

Sesi workshop dilakukan dengan pembagian kelompok berdasarkan topik dan peminatan peserta, dimana setiap kelompok terdiri dari masyarakat umum, akademisi, mahasiswa, stakeholder dan narasumber. Penyampaian draf yang sebelumnya telah disusun oleh tim GHC UNISSULA dipaparkan oleh penanggung jawab kelompok, untuk selanjutnya dilakukan pembahasan oleh narasumber bersama-sama dengan peserta kelompok. Hasil akhir disampaikan dalam forum pleno antar kelompok. 


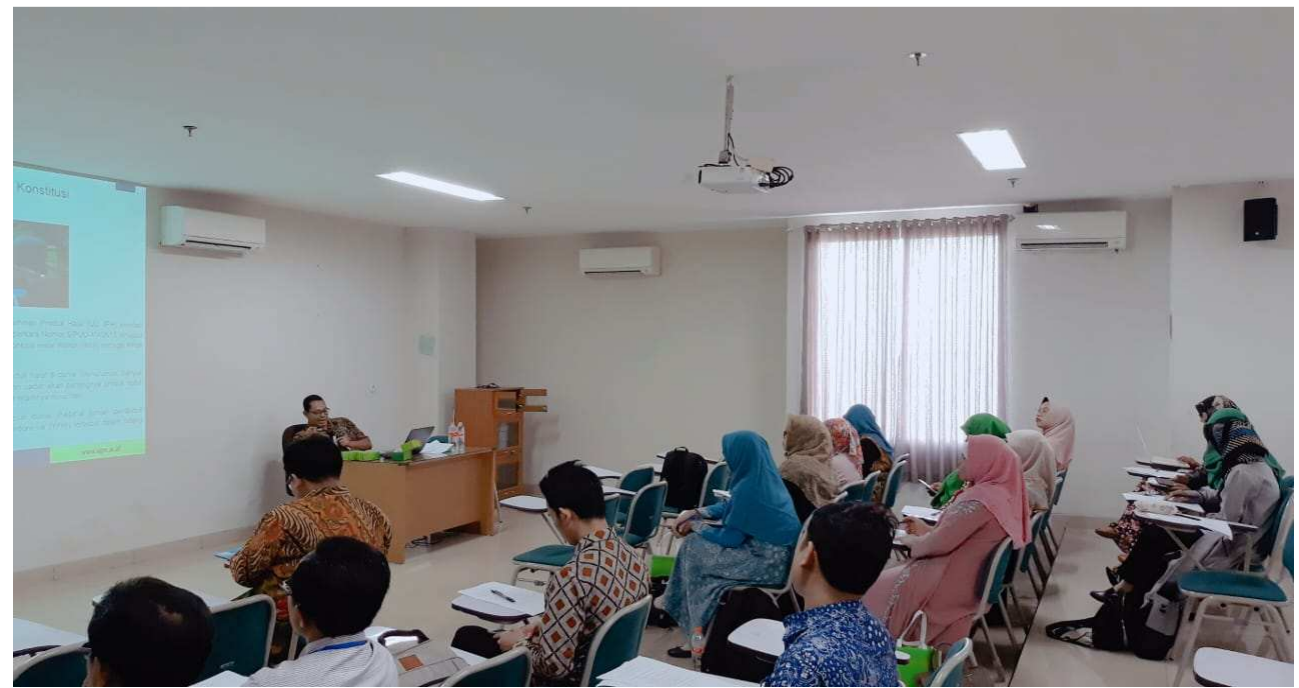

Gambar 4. Aktivitas salah satu kelompok workshop untuk penyusunan instrumen "Muslim Friendly".

\section{HASIL DAN PEMBAHASAN}

\section{Seminar}

Seminar dan workshop sehari yang diselenggarakan oleh GHC UNISSULA diikuti oleh 200 lebih peserta yang berasal dari institusi pendidikan, lembaga terkait, akademisi, masyarakat dan mahasiswa. Pemaparan narasumber memberikan banyak masukkan terkait peluang dan tantangan sertifikasi sektor jasa. Untuk saat ini yang dikembangkan oleh BPJPH masih sebatas makanan dan minumanyang rencana akan diwajibkan mulai bulan oktober 2019 secara bertahap, dan diharapkan 3 hingga 4 tahun kedepan sudah tersertifikasi semua, termasuk minimnya jumlah auditor yang saat ini ada perlu dilakukan penambahan (Santoso, 2019). Untuk sertifikasi halal terhadap obat maka perlu didiskusikan lebih lanjut dengan kementrian kesehatan, hingga saat ini yang menjadi kendala adalah masih minimnya auditor BPJPH dan belum disahkannya PP tentang jaminan produk halal, walaupun undang-undangnya telah ada sejak 2014, yaitu Undang-undang Nomor 33 Tahun 2014 tentang Jaminan Produk Halal. Guna pemenuhan auditor dan sosialisasi jaminan produk halal pada kesempatan tersebut juga ditandatangani naskah kerja sama antara UNISSULA dengan BPJPH oleh Rektor UNISSULA dan ketua BPJPH. 


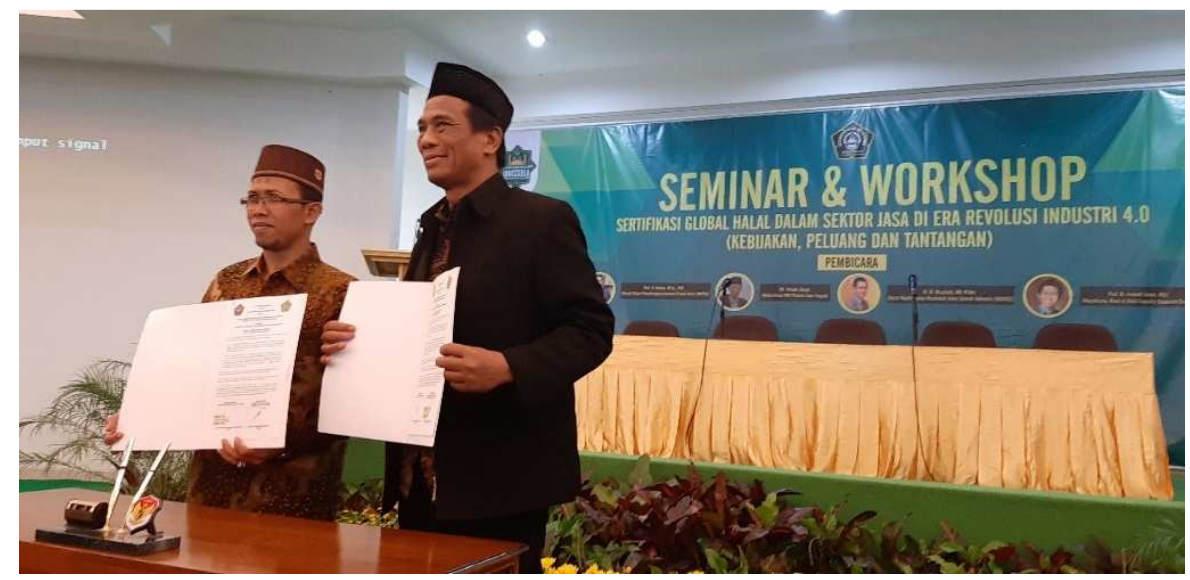

Gambar 5. Penandatangan Naskah Kerjasama antara BPJPH dan UNISSULA

Pemaparan oleh ketua MUI Jateng memberikan gambaran betapa pentingnya perlindungan bagi umat Islam terutama yang berhubungan dengan produk makanan maupun olahan-olahan sejenis, jaminan halal terhadap produk tentu merupakan jawab penting. MUI telah lama merintis sertifikasi halal bekerja sama dengan LP POM untuk obat dan makanan. Material kedokteran dan obat-obatan belum bisa dilakukan sertifikasi halal secara menyeluruh dikarenakan beberapa kendalan di antaranya adalah obat-obatan tertentu yang digunakan di Indonesia yang belum ada alternatif penggantinya.

Pembicara dari Malaysia, tepatnya dari Institute Halal Malaysia, menyampaikan bahwa negara-negara di Asia dan Eropa banyak meminta disertifikasi halal dari lembaganya, sebagai contoh perusahaan kosmetik Korea, restoran di Jepang, dan juga melakukan pelatihan penyembelihan hewan ternak yang syar'i dengan peserta berasal dari New Zealand, bahkan lembaga yang pernah dipimpinnya menemukan beberapa peralatan untuk mendeteksi kandungan alkohol dan alat penyamak kontainer agar kontainer tetap suci untuk mengangkut barang yang akan di ekspor maupun impor agar tidak tercemar dari najis. Prof. Irwandi jaswir dalam narasinya menyampaikan juga bahwa di Malaysia telah banyak dikembangkan instrumen baru untuk sektor jasa perhotelan yang saat ini akan digunakan untuk sebagai sertifikasi Muslim Friendly for tourism di Singapura dan beberapa negara asia dan eropa melalui pemberian crescent rating. Hingga saat ini crescent rating dalam dunia perhotelan untuk kepentingan halal tourism telah banyak dilakukan di luar negeri terutama di negara yang banyak dikunjungi oleh umat Islam sebagai destinasi wisata, walaupun Indonesia tidak termasuk di dalamnya (Hussain, 2015) (CrescentRating, 2018). 
Ketua MUKISI yang juga merupakan narasumber menyampaikan bahwa Dewan Syariah Nasional telah mensyahkan instrumen untuk rumah sakit syariah, dan Rumah Sakit Islam Sultan Agung Semarang sudah terakreditasi sebagai RS syariah yang pertama di Indonesia. Salah satu yang menjadi kendala pada RS Syariah adalah pada pemenuhan obatobatan halal, karena baru sebagian kecil obat yang digunakan di RS berlabel halal, termasuk didalamnya adalah kebutuhan vaksin.

Menyimak isi materi yang disampaikan oleh para narasumber tersebut, dapat menjadi bahan diskusi dan rujukan lebih lanjut terkait peluang-peluang yang bisa dikembangkan oleh kalangan akademisi, di antaranya adalah membantu proses penyediaan auditor halal yang tidak hanya sebatas obat dan makanan, sosialisasi terhadap pentingnya produk halal baik itu berupa barang dan jasa pada masyarakat, penciptaan instrumen syariah untuk sektor jasa, pembinaan pada lembaga penyedia barang dan jasa.

Kegiatan seminar ditutup dengan acara deklarasi GHC UNISSULA bersama narasumber dan peserta yang hadir untuk berkomitmen menyelamatkan umat, deklarasi ditandai dengan penandatangan naskah bertuliskan "Berkhidmat Menyelamatkan Umat" (Gambar 6). Deklarasi tersebut ditandatangani oleh para narasumber, Rektor UNISSULA, pengelola PS GHC, panitia, dan seluruh peserta seminar dan workshop yang hadir. Diharapkan dengan komitmen ini mampu memberikan motivasi pada lembaga untuk senantiasa melakukan kajian untuk melahirkan instrumen-instrumen yang mampu digunakan sebagai indikator oleh para konsumen untuk memilih lembaga yang akan digunakannya.

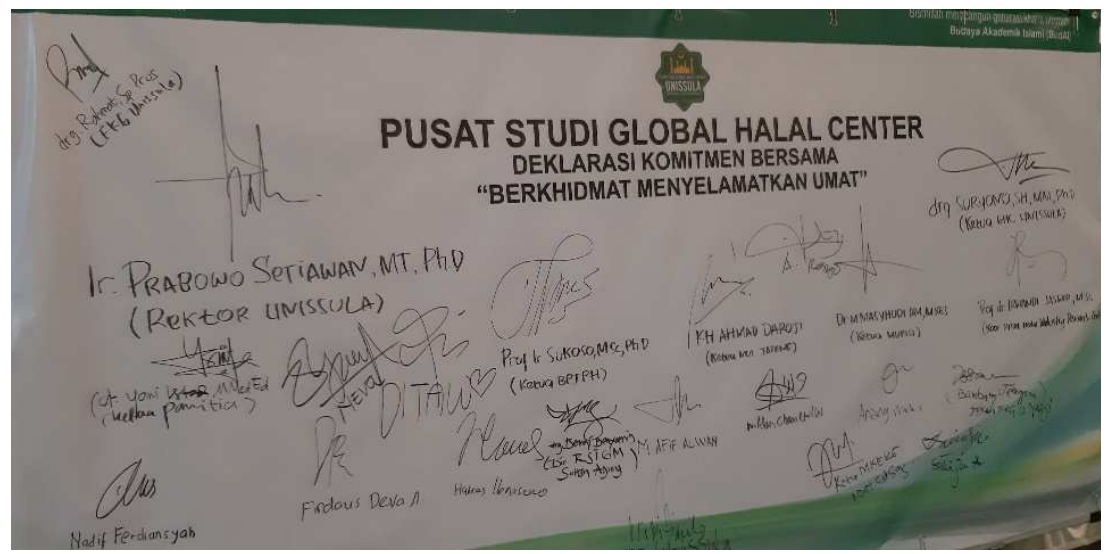






Gambar 6. Deklarasi bersama narasumber dan peserta untuk komitmen berkhidmat menyelamatkan umat.

\section{Workshop Penyusunan Instrumen}

Workshop penyusunan instrumen dilakukan melalui beberapa tahapan di antaranya penyiapan draft oleh panitia berdasarkan kajian dan masukan narasumber internal, dan pembahasan draf yang melibatkan para akademisi, narasumber, stakeholder dan wakil masyarakat. Workshop dilaksanakan dalam 5 grup di ruangan terpisah yang meliputi (1) Instrumen sertifikasi Muslim Friendly untuk apotik, (2) Instrumen sertifikasi Muslim friendy untuk klinik kecantikan, (3) Instrument sertifikasi Muslim Friendly untuk klinik gigi, (4) Instrumen sertifikasi Muslim Friendly untuk pemotongan hewan ternak, dan (5) Instrumen sertifikasi Muslim Friendly untuk keuangan mikro. Penilaian kualifikasi Muslim Friendly terhadap penyedia layanan jasa didasarkan atas karakteristik yang ditentukan dalam item-item instrumen yang menitikberatkan pada keamanan pelanggan atau konsumen bukan pada kelembagaan dari institusi penyedia layanan jasanya, dengan metode rating scale, yang pada akhirnya bisa ditentukan skore dan kualifikasi tingkat kemanan pelayanannya.

Sertifikasi pada sektor jasa hendaknya bisa menjadi prioritas program di Indonesia, hal ini disamping untuk memberikan perlindungan konsumen, juga dalam rangka kepentingan bisnis untuk menangkap peluang sebagaimana dilakukan oleh negara negara lainnya.(CrescentRating, 2018) (Sojung, 2015). Sertifikasi Muslim Friendly yang sudah digalakkan di dunia internasional meliputi jasa perhotelan, restoran, dan transportasi sebagai pendukung sektor pariwisata. (Khan, 2017). Penyediaan daging halal untuk restoran dan hotel merupakan faktor pendukung yang perlu diperhatikan, oleh penyedia jasa pariwisata, hal ini menjadi sangat penting bagi konsumen muslim, oleh karena itu tidak mengherankan jika saat ini dikembangkan juga sertifikasi halal untuk tempat pemotongan hewan ternak di beberapa negara bagian amerika, dan negara pengekspor daging halal.(Hanson, 2012)(Rahma, 2015). Indonesia 
nampaknya perlu berbenah untuk mengikuti gerak perubahan mereka, bahkan mestinya Indonesia bisa menjadi role model bagi negara-negara lain mengingat negara Indonesia mayoritas penduduknya muslim walaupun bukan negara Islam.

Pada sektor jasa pelayanan kesehatan, sertifikasi halal untuk dental klinik telah dilakukan untuk pertama kalinya di India pada November 2018 (Gold Dental, 2018), begitu juga untuk klinik kecantikan mulai diinisiasi oleh beberapa klinik di malaysia melalui penggunaan material kosmetik berlabel halal. Sedang di Indonesia untuk pelayanan kesehatan di rumah sakit telah dirintis oleh Rumah Sakit Islam Sultan Agung Semarang dengan label sertifikasi Rumah Sakit syariah Mumtaz (Wahyu Sulistiadi, 2018). Sektor pendukung dalam jasa pelayanan kesehatan yang tak kalah penting adalah farmasi sebagai unit penyedia obat dan bahan yang digunakan dalam pelayanan kesehatan, walau tidak kita pungkiri bahwa masih banyak obat yang menggunakan material dasar yang berbahan tidak suci, namun dipandang perlu adanya instrumen pendukung dan tatalaksana penggunaannya ke pasien. Telisik dokumen obat menjadi bagian penting pada awal pengkasifikasian apakah obat/material kedokteran yang disediakan masuk dalam kategori halal, meragukan atau haram. Adanya informasi ini akan memudahkan dokter atau tenaga kesehatan untuk memberikan penjelasan dan meminta persetujuan pasien terkait dengan penggunaanya sebagai bentuk penghormatan terhadap hak peribadatan pasien muslim.

Sektor jasa keuangan syariah telah mulai menggeliat di Indonesia, terbukti banyak berdiri bank berlabel syariah, koperasi simpan pinjam syariah, dan telah diluncurkannya lembaga sertifikasi profesi keuangan syariah yang berlisensi dari Otoritas Jasa Keuangan (OJK) dan Badan Nasional Sertifikasi Profesi (BNSP) (Fadila, 2016). Melihat fenomena yang terjadi di luar negeri maupun di Indonesia pada sektor jasa tersebut PSGHC UNISSULA menjadikan sebagai suatu tantangan dan peluang untuk melakukan pengkualifikasian terhadap penyelenggara usaha sektor jasa dengan melihat tatalaksana pelayanan yang berkaitan dengan tingkat keamanan dan kenyamanan konsumen muslim melalui penyusunan intrumen "Muslim Friendly". Penggunaan istilah Muslim Friendly ini lebih ditujukan pada tingkat kepatuhan terhadap tata nilai dalam ajaran Islam, bukan pemberian sertifikasi halal. Kosa kata yang dipilih untuk bahasa inggrisnya adalah "muslim" bukan moslem, walaupun keduanya bermakna sama, namun dalam trend penggunaan istilah "muslim" lebih familiar hingga saat ini.(writing explained, no date). Pertimbangan lain tidak menggunakan istilah syariah adalah terkait dengan target utama yang akan disertifikasi adalah bukan pada unsur kelembagaannya, tetapi pada tatalaksana pelayanan terhadap konsumenya, hal ini berbeda dengan instrumen panduan untuk sertifikasi rumah sakit syariah yang menekankan pada lembaga yang harus beraktivitas secara 
Indonesian Journal of Community Services

E-ISSN: 2684-8619

Volume 1, No. 1, May 2019

http://jurnal.unissula.ac.id/index.php/ijocs DOI: http://dx.doi.org/10.30659/ijocs.1.1.1-15

islami (Mukisi, 2018) Instrumen Muslim Friendly ini dimaksudkan untuk sertifikasi tata laksana pelayanan pada konsumen sehingga membuka peluang bagi institusi yang tidak berbasis Islam pun untuk mendapatkan sertifikasi tersebut. Sektor jasa tersebut meliputi jasa klinik kecantikan, klinik gigi, apotek, keuangan mikro terkait dengan simpan pinjam, dan jasa penyembelihan hewan ternak. Bertitik tolak dari peluang dan tantangan tersebut tim penyusun dari GHC UNISSULA bersama peserta workshop melakukan penyempurnaan terhadap standar, komponen, dan elemen yang sudah dirumuskan sebelumnya. Salah satu instrumen yang telah dilakukan kajian sebelumnya adalah Muslim Friendly for Dental Clinic bersama Forum Komunikasi Kedokteran Gigi Islam Indonesia (FOKGII) yang menghasilkan 4 standar dengan 19 komponen dan 43 elemen penilaian. Pada kesempatan yang sama dalam forum tersebut ditindak lanjuti upaya kerjasama antara komponen FOKGII antara FKG UNISSULA dengan FKG Yarsi melalui penandatanganan MoU dari kedua institusi tersebut.

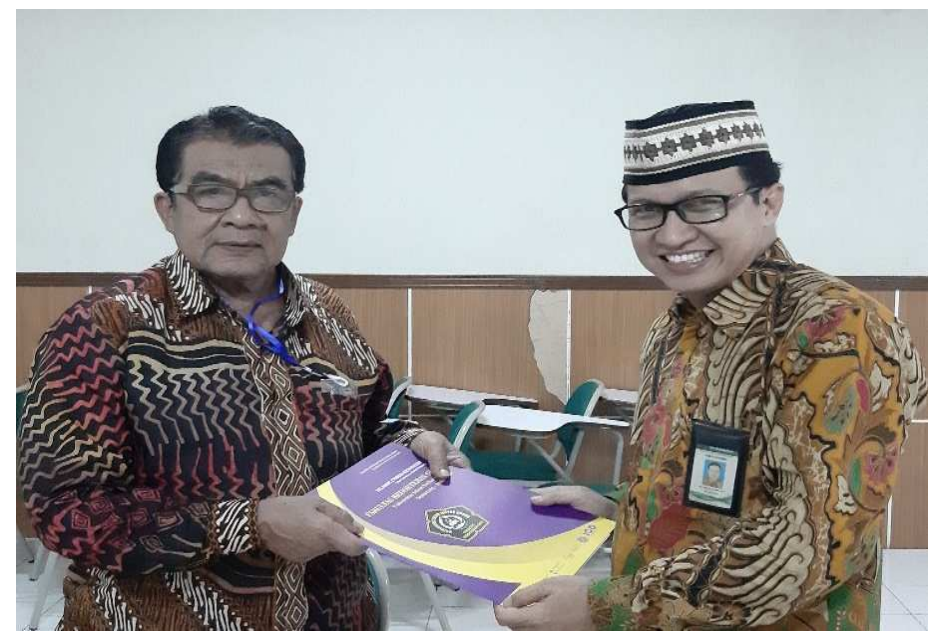

Gambar 7. Penyerahan naskah MoU antara dekan FKG Yarsi dengan dekan FKG UNISSULA

Penyempurnaan item standar, komponen, dan elemen dilakukan dengan melibatkan para stakeholder sehingga didapatkan hasil kesepakatan yang dituangkan dalam instrumen Muslim Friendly pada setiap bidang kajian yang akan dituangkan dalam wujud buku pedoman sertifikasi Muslim Friendly Pusat Studi Global Halal Center UNISSULA. Secara keseluruhan hasil workshop instrumen yang telah disusun tertera pada tabel di bawah ini. 
Tabel 1. Rangkuman Hasil Penyususnan Instrumen Muslim Friendly untuk 5 Pelayanan Jasa

\begin{tabular}{lcc}
\hline $\begin{array}{c}\text { Grup Instrumen } \\
\text { Muslim Friendly Versi 1: 2019 }\end{array}$ & $\begin{array}{c}\text { Jumlah standar; komponen: } \\
\text { elemen }\end{array}$ & $\begin{array}{l}\text { Kualifikasi } \\
\text { Muslim Friendly }\end{array}$ \\
\hline Apotek & $11 ; 17: 42$ & Pratama,Utama, Paripurna \\
Klinik Gigi & $4 ; 19: 43$ & Pratama,Utama, Paripurna \\
Klinik Kecantikan & $13 ; 16: 73$ & Pratama,Utama, Paripurna \\
Pemotongan Hewan & $3 ; 6 ; 23$ & Pratama,Utama, Paripurna \\
Keuangan mikro & $3 ; 22: 145$ & Pratama,Utama, Parpurna \\
\hline
\end{tabular}

Secara garis besar standar yang dinilai untuk setiap instrumen meliputi manajemen, sumber daya insani, Sarana, prasarana pendukung, dan Penatalaksanaan. Detail dari Instrumen Muslim Friendly Versi 1 untuk setiap grup akan dipublikasikan dan bisa digunakan oleh lembaga pengakreditasi manapun setelah setelah di daftarkan pada kemenkumham untuk mendapatkan Hak Atas Kekayaan Intelektual (HAKI). Pedoman baku yang bisa dipertanggungjawabkan secara akademik untuk melakukan rating scale Muslim Friendly pada sektor jasa layanan publik menjadi sangat penting di era milenial saat ini, hal ini didasarkan pada pengamatan yang terjadi di lapangan adanya lembaga yang dengan serta merta mencatumkan label halal/syariah/ islami/sahabat muslim/ aman untuk muslim dan sejenisnya untuk sektor jasa. Pusat studi global halal UNISSULA sangat berharap dengan terbentuknya pedoman ini bisa digunakan oleh institusi/lembaga penyedia layanan jasa untuk bisa berbenah menuju pada label Muslim Friendly yang terstandarisasi dengan baik, sehingga konsumen muslim benar-benar bisa mendapatkan hak-haknya tanpa melanggar ketentuan agama Islam yang dianutnya.

Kualifikasi lembaga terhadap tingkat keamanan konsumen berdasarkan skore rating scale akan dibagi menjadi 3 kualifikasi yakni (1) Muslim Friendly jenjang pratama (***), bila semua elemen primer bisa dipenuhi, (2) Muslim Friendly jenjang utama (****), bila lembaga dalam pelayanannya memenuhi standar primer dan tersier dan (3) Muslim Friendly jenjang paripurna (*****) bila lembaga dalam memberikan pelayanan dan fasilitas memenuhi instrumen primer, sekunder dan tersier. Pengklasifikasian ini mengacu pada pertimbangan karakteristik kelengkapan perijinan Institusi, sumber daya manusia, sarana/prasarana dan standar prosedur operasional pelayanan yang dimiliki.

Lembaga/institusi/unit yang menyelenggarakan bisnis layanan jasa tersebut tentu akan mendapatkan manfaat sebagai nilai plus yang merupakan daya tarik tersendiri bagi pelanggan muslim. Keyakinan akan keamanan dalam penatalaksanaan yang terbentuk pada diri konsumen, 
akan menggeser kedudukan konsumen biasa menjadi konsumen yang loyal. Satu koma delapan milyar penduduk Muslim dunia merupakan pangsa pasar yang besar untuk sektor jasa yang potensial secara ekonomi, dimana lebih dari 200 juta bermukim di Indonesia. Tentu bagi para pengusaha ini adalah peluang yang bisa digarap dan dioptimalkan dengan baik. Dampak yang akan dirasakan oleh konsumen muslim tentu secara psikologis merasa lebih aman, nyaman dan tidak lagi meragukan terhadap jasa, barang atau produk yang mereka peroleh dari lembaga yang telah mendapatkan label Muslim Friendly tersebut.

\section{KESIMPULAN}

Penduduk muslim sebagai konsumen penerima layanan sektor jasa hendaknya diberikan perlakuan yang bisa menjamin bahwa produk yang diterima baik itu berupa barang dan jasa tidak bertentangan dengan nilai-nilai ajaran agamnya dan pemberian informasi terhadap jasa dan barang yang diperjualbelikan harusnya bisa diketahui oleh para calon konsumen semaksimal mungkin. Universitas Islam Sultan Agung Semarang sebagai perguruan tinggi yang berbasis Islam merasa terpanggil untuk lebih memperhatikan keamanan dan keselamatan umat terhadap pelayanan jasa yang diterima oleh konsumen melalui kajian-kajian halal dan penyususnan instrumen syariah, sebagai wujud bentuk pengabdian kepada masyarakat.

Pusat Studi Global Halal Center-UNISSULA melakukan penyusunan instrumen tersebut melalui kegiatan seminar dan workshop penyusunan instrumen Muslim Friendly dengan melibatkan stakholder, narasumber, dan masyarakat. Hasil kegiatan tersebut melahirkan instumen Muslim Friendly untuk 5 lembaga penyelenggaran layanan jasa meliputi; (1) Muslim Friendly untuk dental klinik, (2) Muslim Friendly untuk klinik kecantikan, (3) Muslim Friendly untuk apotek, (4) Muslim Friendly untuk keuangan mikro, (5) Muslim Friendly untuk rumah pemotongan hewan ternak, dan tambahan 1 suplemen pendukung untuk telisik dokumen untuk obat.

Kelima jenis instrumen Muslim Friendly tersebut akan dijadikan buku panduan dan akan didaftarkan pada Kemenkumham untuk mendapatkan Hak atas Kekayaan Intelektual, sebagai Instrumen Muslim Friendly Versi 1- GHC UNISSULA. Instrumen ini ke depannya dapat digunakan oleh lembaga sertifikasi sektor jasa, untuk pembinaan, assesmen dan pemberian label Muslim Friendly dengan kualifikasi pratama, utama, dan paripurna.

Adanya labelisasi Muslim Friendly pada institusi penyelenggara layanan jasa diharapkan bisa berkontribusi secara nyata dalam menyelamatkan umat, melalui pemberian pelayanan jasa yang aman berdasarkan nilai-nilai ajaran Islam. Labelisasi Muslim Friendly ini bukan 
merupakan pensertifikasian halal suatu sektor jasa, namun lebih pada tingkat kepatuhan terhadap nilai-nilai Islam, sehingga sebagai konsumen bisa merasa aman dan nyaman dalam menggunakan produknya.

\section{UCAPAN TERIMA KASIH}

Ucapan terima kasih ditujukan kepada Yayasan Badan Wakaf Sultan Agung, Jajaran Rektorat UNISSULA yang telah memberikan dukungan pembiayaan dan fasilitasi perijinan, LPPM UNISSULA yang telah memberikan arahan, para narasumber Ketua MUI Jateng KH Ahmad Daroji, Kepala BPJPH Prof. Ir. Sukoso, Ketua Umum MUKISI dr. H. Masyhudi AM, M.Kes dan Prof. Irwandi Jaswir dari International Institute for Halal Training (INHART) Malaysia atas sharing ilmunya dan para peserta atas partisipasi dan dukungannya, sehingga acara kegiatan ini bisa berjalan lancar dan bisa menghasilkan produk berupa 5 jenis instrumen sertifikasi Muslim Friendly untuk sektor jasa.

\section{DAFTAR PUSTAKA}

Aminah, A. N. (2019) 'Pemprov Sulsel Kembangkan Program Moslem Friendly di Toraja'. Available at: https://nasional.republika.co.id/berita/nasional/daerah/pnwg24384/pemprov-sulselkembangkan-program-moslem-friendly-di-toraja.

Anugeraha, T. S. (2014) 'Moslem Lifestyle and Halal Food in Osaka'. Available at: https://www.halalmedia.jp/archives/554/moslem-lifestyle-halal-food-osaka/\%0D.

CrescentRating (2018) GLOBAL MUSLIM TRAVEL INDEX 2018. Available at: https://www.crescentrating.com/download/thankyou.html?file=X7UrOM8Y_GMITIReport-2018-web-version\%281\%29.pdf.

Fadila, I. (2016) Lembaga Sertifikasi Profesi Keuangan Syariah Diluncurkan. Available at: https://finansial.bisnis.com/read/20160729/232/570368/lembaga-sertifikasi-profesikeuangan-syariah-diluncurkan.

Gold Dental (2018) Gold Dental Care - OMR Branch is now Halal Certified. First and Only Dental Clinic to be Halal Certified! Available at: https://www.golddentalcare.com/golddental-care-omr-branch-now-halal-certified-first-dental-clinic-halal-certified/.

Hanson, T. (2012) NABC Visits Bukhari/Waqas Muslim Slaughterhouse in Duvall. Available at: https://www.agbizcenter.org/blog/2012/07/nabc-visits-bukhariwaqas-muslimslaughterhouse-in-duvall/.

Hussain, T. (2015) 'Muslim History Tours: pioneering London minnow that took on global halal travel heavyweights'. Available at:

https://www.salaamgateway.com/en/story/muslim_history_tours_pioneering_london_m innow_that_took_on_global_halal_travel_heavyweights-SALAAM10112015125820/.

Khan, T. (2017) 'Muslim Heritage and History Bus Tour'. Available at: www.britishmuslimmagazine.com/2017/04/23/muslim-heritage-history-bus-tour/\%0D.

Mukisi (2018) Standar dan Sertifikasi Rumah Sakit Syariah. Available at: 
https://mukisi.com/503/standar-dan-sertifikasi-rumah-sakit-syariah/\%0D.

Rahma, M. (2015) 'Rumah Pemotongan Hewan Halal Makin Menjamur di Amerika Serikat'. Available at: https://news.detik.com/berita/d-2949091/rumah-pemotongan-hewan-halalmakin-menjamur-di-amerika-serikat.

Santoso, H. (2019) 'Indonesia Kekurangan Auditor Produk Halal'. Available at: https://www.suaramerdeka.com/news/baca/171781/indonesia-kekurangan-auditorproduk-halal\%0D.

Sigit (2016) 'Dengan Tagline Moslem friendly Destination, Sumbar Siap Kembangkan Wisata Halal'. Available at: https://bimasislam.kemenag.go.id/post/berita/dengan-taglinemoslem-friendly-destination-sumbar-siap-kembangkan-wisata-halal\%0D.

Sojung, Y. (2015) KTO publishes halal guidebook. Available at: http://www.korea.net/NewsFocus/Travel/view?articleId=124713 (Accessed: 22 March 2019).

Suryono, S. (2015) 'Pengaruh Cara Aplikasi Pasta Gigi Herbal terhadap Produksi Volatile Sulfur Compound', Majalah Kedokteran Gigi Indonesia, 20(2), p. 172. doi: 10.22146/majkedgiind.9122.

Suryono, S. et al. (2017) 'Propolis 10\%-Gel as a Topical Drug Candidate on Gingivitis', International Journal of Medicine and Pharmacy. doi: 10.15640/ijmp.v5n1a2.

wahyu sulistiadi, R. S. (2018) 'ASSESSMENT OF FIRST SHARIA HOSPITAL CERTIFICATION IN INDONESIA FACING THE GLOBAL COMPETITION', in writing explained (no date) Moslem vs. Muslim: What's the Difference? Available at: https://writingexplained.org/moslem-vs-muslim-difference. 